\title{
Conditional conservatism and cost of capital
}

\author{
Juan Manuel García Lara • Beatriz García Osma • \\ Fernando Penalva
}

\begin{abstract}
We empirically test the association between conditional conservatism and cost of equity capital. Conditional conservatism imposes stronger verification requirements for the recognition of economic gains than economic losses, resulting in earnings that reflect losses faster than gains. This asymmetric reporting of gains and losses is predicted to lower firm cost of equity capital by increasing bad news reporting precision, thereby reducing information uncertainty (Guay and Verrecchia 2007) and the volatility of future stock prices (Suijs 2008). Using standard asset pricing tests, we find a significant negative relation between conditional conserva tism and excess average stock returns over the period 1975 2003. This evidence is corroborated by further tests on the association between conditional conservatism and measures of implied cost of capital derived from analysts' forecasts.
\end{abstract}

Keywords Conditional conservatism - Asymmetric reporting - Cost of capital . Information precision - Uncertainty

JEL Classification $\mathrm{G} 10 \cdot \mathrm{G} 38 \cdot \mathrm{M} 41$

J. M. García Lara

Department of Business Administration, Universidad Carlos III de Madrid, Calle Madrid 126, 28903 Getafe, Spain

e-mail: jmglara@emp.uc3m.es

B. García Osma

Department of Accounting, Universidad Autónoma de Madrid, Fco. Tomás y Valiente 5, 28049 Madrid, Spain

e-mail: beatriz.garcia@uam.es

F. Penalva $(\bowtie)$

IESE Business School, University of Navarra, Avenida Pearson 21, 08034 Barcelona, Spain e-mail: penalva@iese.edu 


\section{Introduction}

We examine the association between conditional accounting conservatism and cost of equity capital. Conditional conservatism imposes stronger verification require ments for the recognition of economic gains than economic losses, generating earnings that reflect bad news in a timelier fashion than good news. This is referred to as the asymmetric timeliness of earnings (Basu 1997). Recent analytical work by Guay and Verrecchia (2007) and Suijs (2008) coincides in arguing that asymmetric reporting can affect firm's market value and its cost of equity capital. These authors analytically demonstrate that more precise bad news reporting reduces (1) the discount that investors apply to firm value in the presence of uncertainty and (2) the volatility of future stock prices (and thus shareholders' investment risk). In this paper, we empirically test this proposition and provide evidence on the negative association between asymmetric reporting and cost of equity capital.

Guay and Verrecchia (2007) articulate the mechanism underlying the predicted relation between conditional conservatism and cost of capital. They show that firm commitment to timely reporting of low realizations leads to full disclosure of information and lower cost of capital. In their model, uncertainty about the information structure leads to the appearance of risk premiums as investors place less weight on imprecise information signals (Merton 1987; Easley and O'Hara 2004; Lambert et al. 2008), and full disclosure of information reduces the uncertainty about expected future cash flows, lowering cost of capital. Full disclosure is achieved via timely recognition of difficult to verify losses in the audited financial statements combined with voluntary strategic disclosure of good news through various other information channels, which are expected to flourish in the presence of conservative reporting (LaFond and Watts 2008).

Suijs (2008) suggests an alternative link between firm reporting policy and cost of capital. In his model, overlapping generations of shareholders invest in a firm with a life cycle that exceeds shareholders' investment horizons. In such a setting, it is the volatility of firm future prices that determines investment risk and not the volatility of future cash flows. As a result, firm reporting policies become a primary determinant of investment risk. More informative disclosure of bad news reduces the cost of capital by improving risk sharing across generations of investors. Suijs (2008) demonstrates that an asymmetric reporting system that reports bad news more precisely than good news results in higher firm value and more efficient risk sharing.

While regulators and corporate executives appear to believe that accounting decisions can have cost of capital effects (Levitt 1998; Graham et al. 2005), recent work on the association between financial information attributes and cost of capital presents mixed theories and conflicting evidence (Easley and O'Hara 2004; Lambert et al. 2007; Core et al. 2008; Hughes et al. 2009). We add to this prior literature by empirically testing the proposition in Guay and Verrecchia (2007) and Suijs (2008) that conditional conservatism leads to lower cost of capital. ${ }^{1}$ With the exception of

\footnotetext{
${ }^{1}$ For brevity, we sometimes refer to conditional conservatism simply as conservatism. Similarly, we use the terms cost of capital and cost of equity capital interchangeably.
} 
some limited evidence in Francis et al. (2004), no prior study has analyzed the association between conditional conservatism and cost of capital.

Using a large sample of US firms for the period 1975 2003, we create and validate a firm specific measure of conservatism (Conservatism) based on the work of Callen et al. (2010). We use this proxy in asset pricing regressions to test whether more conditionally conservative firms experience lower expected stock returns. The asset pricing tests yield the following key evidence. We document a significant and negative coefficient on the Conservatism portfolio in a firm specific time series regression that correlates returns contemporaneously with Conservatism, the three Fama and French (1993) risk factors (beta, size, and book to market) and a momentum factor (Carhart 1997). Second, we examine whether a strategy that buys (sells) firms with high (low) Conservatism earns abnormal returns. We find that the Conservatism hedge portfolio strategy yields significantly negative abnormal excess returns. Finally, we build a Conservatism mimicking portfolio called AMC (Aggressive minus Conservative) by subtracting each month the value weighted return of stocks in the highest three deciles of Conservatism from the value weighted return of stocks in the lowest three deciles of Conservatism. Using a two stage cross sectional regression technique extensively used in the finance literature, we show that the AMC factor loading is significantly positive on a cross sectional regression of portfolio returns on AMC, momentum, and the three Fama and French factor loadings.

We check the robustness of our findings in several ways. First, we assess the construct validity of the Callen et al. (2010) conservatism proxy. Second, we provide empirical evidence consistent with the analytical frameworks of Guay and Verrecchia (2007) and Suijs (2008) that conditional conservatism is associated to lower earnings forecast errors and lower future returns volatility. Finally, following prior work by Francis et al. (2004), among others, we assess the association between conservatism and cost of capital as measured by the expected return of a firm's stock implicit in analysts' forecasts. To do so, we regress a measure of implied cost of capital on Conservatism, risk proxies, and controls for the determinants of conditional conservatism. This provides additional indirect evidence of the link between conditional conservatism and cost of equity. The results from these tests corroborate the findings from the asset pricing tests.

Overall, we document a robust negative association between conditional conservatism and cost of capital, consistent with the propositions in Guay and Verrecchia (2007) and Suijs (2008). Our results add to the recent stream of empirical literature on the cost of capital effects of variation in accounting quality ${ }^{2}$ and contribute to a flourishing stream of empirical research in accounting conservatism that shows that conditional conservatism is associated to positive economic outcomes (Bushman et al. 2007; Ahmed and Duellman 2008; LaFond and

\footnotetext{
2 See Botosan (1997), Botosan and Plumlee (2002), Battacharya et al. (2003), Francis et al. (2004, 2005), Hribar and Jenkins (2004), Aboody et al. (2005), Barth et al. (2010), Kravet and Shevlin (2007), McInnis (2010), Francis et al. (2008), Core et al. (2008), Daske et al. (2008). The evidence presented by this literature is somewhat mixed, which is partly attributable to the different empirical methods used, as well as the use of accounting quality proxies, such as disclosure, transparency or income smoothing, with a tenuous link with information precision about future cash flows.
} 
Watts 2008; Francis and Martin 2010). The reported evidence sheds some additional light on the regulatory debate on whether conservatism should be excluded from the desirable qualitative characteristics of accounting information.

The remainder of the paper is structured as follows. Section 2 contains the discussion on the expected relation between conservatism and cost of equity and reviews prior work on the topic. Section 3 describes the asset pricing tests to empirically analyze this relation, the empirical measure of conditional conservatism that we use in our tests, and how we validate this conservatism measure. Section 4 presents the data and the empirical results. Section 5 discusses the robustness tests. Finally, Section 6 summarizes the findings and concludes.

\section{The association between conditional conservatism and cost of capital}

Conditional conservatism, defined following Basu (1997) as the implementation of more stringent verifiability criteria for the recognition of good news than bad news in earnings, is one of the most pervasive characteristics of accounting information. This pervasiveness is explained by the expected benefits of conditional conserva tism for the different parties to the firm. Prior literature on conservatism highlights the benefits of conservatism in contracting (Watts 2003). Conditional conservatism acts as a governance mechanism that benefits both debt and equity holders and increases firm value. ${ }^{3}$ Watts (2003) maintains that this increase in firm value is achieved by minimizing contracting, litigation and regulatory and taxation costs. In addition to these contracting benefits of conservatism, LaFond and Watts (2008) argue that conditional conservatism is expected to "lower information asymmetry between managers and outside investors" and that "conservative financial reports are likely to generate a more informed capital market."4

Furthering our understanding of the role of conditional conservatism in improving the functioning of capital markets, Guay and Verrecchia (2007) make the argument that the preference for an asymmetric reporting system "lies in the discount the market applies to uncertainty in the absence of information." 5 They argue that managers have incentives to act strategically and disclose information only on good prospects and high realizations (Dye 2001). In the absence of regulatory enforcement of conservative reporting, managers recognize good news in earnings on a timely basis and voluntarily disclose higher bounds for future expected cash flows. However, they shy away from full disclosure by deferring the recognition of difficult to verify losses and withholding information about low realizations of expected future cash flows. Guay and Verrecchia (2007) develop a model where markets anticipate strategic disclosure and apply a discount if there is certainty that management is withholding information. Against this backdrop, when

\footnotetext{
3 Consistent with this view, Beekes et al. (2004), Ahmed and Duellman (2007), and García Lara et al. (2009a) show that better governed firms report more conditionally conservative numbers, while the work of Ball et al. (2008) confirms that both debt and equity markets demand conservative accounting.

${ }^{4}$ See pages 448 and 458 in LaFond and Watts (2008).

${ }^{5}$ Guay and Verrecchia (2007) page 3.
} 
conservative reporting is enforced, the market can be certain that no information is withheld.

Guay and Verrecchia (2007) analytically demonstrate that a commitment to an asymmetric reporting system permits attaining full disclosure. Good and bad news is disclosed on a timely basis, although through different communication channels. Bad news is recognized in the income statement, while good news is disclosed through other channels like the notes to the financial statements, conference calls, etc. These sources of information flourish under conservatism (LaFond and Watts 2008). Under full disclosure, market participants have timely information both on the lower and upper bounds of firm future cash flows. This reduces information uncertainty and increases the precision with which investors can assess firm future cash flows, minimizing the discount markets apply to firm value. Consistent with this view, Lambert et al. $(2007,2008)$ show that, more generally, by improving accounting information quality, managers increase the precision with which market participants can assess firm future cash flows and thus reduce cost of capital. They demonstrate that this effect is not diversifiable, even in large economies. Along these lines, it is not unreasonable to assume that conservatism is so embedded into financial reporting practices that diversification may not be possible.

Conditional conservatism is also expected to increase firm value indirectly through improved monitoring and contracting and reduced litigation costs. As shown by Guay and Verrecchia (2007) conservatism increases firm value (1) by improving corporate governance (which, in turn, allows early removal of poorly performing managers, prevents managers from engaging in self serving projects and expropriating investors, improves firm investment efficiency, etc.), (2) by reducing agency costs arising from compensation and debt contracting, and (3) by reducing litigation costs. These arguments link to the work in Lambert et al. (2007), who show that there is also an indirect link between information quality and cost of equity.

Finally, Suijs (2008) provides an alternative link between conservatism, information precision, and cost of capital. He builds a model of overlapping generations of shareholders that invest in a firm with a life cycle that exceeds shareholders' investment horizons. In that setting, investment risk is determined by the dispersion of future stock prices and not by the volatility of future cash flows. Suijs (2008) demonstrates that an asymmetric reporting system that reports bad news more precisely than good news results in higher firm value and more efficient risk sharing amongst generations of investors. Suijs argues that firm reporting policies are a primary determinant of investment risk and that a conservative reporting system serves to reduce this risk, thereby lowering firm cost of capital.

There has been little empirical research on this topic. Only the work of Francis et al. (2004) examines the relation between cost of equity capital and conditional conservatism at the firm year level. They study the link between cost of capital and seven earnings attributes: accrual quality, persistence, predictability, smoothness, value relevance, timeliness, and conservatism. They hypothesize and find that, generally, more favorable values of the individual earnings attributes are associated with lower cost of capital, after controlling for known risks factors and innate determinants of the earnings attributes. However, they do not find evidence of an 
association between conservatism and cost of equity. Their result of no relation is probably driven by measurement error in their firm level proxy of conservatism, as demonstrated by Givoly et al. (2007), and by the use of tests that rely solely on the use of ex ante cost of capital estimates that have been shown to be unduly affected by optimism in analysts' earnings forecasts (Easton and Sommers 2007). More recently, $\mathrm{Li}$ (2009) studies the effect of conditional conservatism on the cost of debt and equity capital at the country level. Using an empirical design based on the classical Basu (1997) model and ex ante measures of the cost of equity, she finds that firms from countries with more conservative financial reporting systems have significantly lower cost of debt and equity, after controlling for differences in legal institutions and securities regulations. We depart from Francis et al. (2004) and Li (2009) in three main ways: (a) we use a firm level measure of conditional conservatism (as in Callen et al. 2010) to overcome the possible biases in the Basu (1997) measure described by Dietrich et al. (2007), Givoly et al. (2007) and Patatoukas and Thomas (2009); (b) we do not rely on ex ante measures of the cost of equity; and (c) we use formal asset pricing tests widely used in the finance literature.

\section{Research design}

Aboody et al. (2005), Francis et al. (2005), Core et al. (2008), Francis et al. (2008), and McInnis (2010) use asset pricing tests to assess whether accounting choice affects firm cost of capital. We follow their approach and study (1) whether conditional conservatism is associated with future firm specific and portfolio excess returns and (2) whether conditional conservatism is a priced factor in a Fama and French (1993) factor model setting, using the two stage cross sectional regression method common in the finance literature after Fama and MacBeth (1973).

\subsection{Conditional conservatism and future excess returns}

As a first test, we study whether conditional conservatism predicts future excess returns. To do so, we regress firm specific future excess returns on firm characteristics and conditional conservatism (Conservatism). We match annual estimates of beta, size, book to market, momentum, and Conservatism to monthly returns in the next 12 months starting 4 months after the fiscal year end. That is, for December fiscal year ends we collect monthly returns from April of year $t+1$ to March of year $t+2$. The model is run monthly as follows:

$$
\begin{aligned}
R_{i, t+1} \quad R_{F, t+1}= & \alpha+\beta_{1} \text { Beta }_{t}+\beta_{2} \text { Size }_{t}+\beta_{3} \text { BM }_{t}+\beta_{4} \text { Momentum }_{t} \\
& +\beta_{5} \text { Conservatism }_{t}+\mu_{t}
\end{aligned}
$$

where monthly excess returns $\left(R_{i, t+1} \quad R_{F, t+1}\right)$ are measured in percentages and are calculated as the raw stock return less the risk free rate. The raw stock return is obtained from the CRSP monthly stock file, and the risk free rate is the return on the 1 month T bill obtained from the Fama French files at WRDS. Beta is the slope coefficient from a regression of a firm's monthly excess returns on the monthly 
value weighted market excess return over a rolling 60 month window ending in the current fiscal year. Size is the natural log of the market value of equity measured at the end of the year. $B M$ is the $\log$ of the book to market value of equity ratio. Momentum is the buy and hold return for the 11 month period ending 1 month prior to the end of the year. We include momentum in all our tests because high conservatism firms are more likely to have negative returns, and we want to ensure that the results are not an artifact of momentum. Conservatism is the monthly decile ranks of the three year average of the firm year specific proxy of conditional conservatism developed in Callen et al. (2010). Section 3.3 below provides details on the calculation and validation of Conservatism as a firm specific proxy for conditional conservatism. In model (1) the main coefficient of interest is $\beta_{5}$. If conditional conservatism lowers cost of equity capital, this will lead to lower future excess returns and a significantly negative $\beta_{5}$ coefficient.

As a second test, we follow a similar approach to the one in Gompers et al. (2003), Aboody et al. (2005), Core et al. (2008) and Francis et al. (2008); and test whether an investment strategy that buys (sells) firms in the decile with the largest (smallest) conditional conservatism earns negative abnormal returns. To perform this test, each month, from Jan. 1, 1976 to Dec. 31, 2004 (348 months), all firm years in the sample are ranked into 10 deciles based on their Conservatism value. Portfolios of stocks are then formed for each Conservatism decile. Then, for every Conservatism decile, we estimate the following time series regression of monthly value weighted portfolio returns on the three Fama and French (1993) factors and a momentum factor:

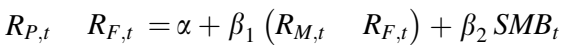

$$
\begin{aligned}
& +\beta_{3} H M L_{t}+\beta_{4} U M D_{t}+\mu_{t}
\end{aligned}
$$

where $R_{P} \quad R_{F}$ equals the value weighted return on the portfolios less the risk free rate. $R_{M} \quad R_{F}$ is the excess return on the value weighted market portfolio. SML is the value weighted size mimicking portfolio return. HML is the value weighted BM mimicking portfolio return. UMD is the value weighted momentum mimicking portfolio. $R_{M} \quad R_{F}$, SMB, HML, and UMD are obtained directly from WRDS. Monthly returns are measured in percentages. The main coefficient of interest in Eq. 2 is the intercept. If the model is well specified, the intercept should be very close to zero and insignificant. However, if the variable used to create the portfolios is priced by the market (or the market is mispricing the information, as in Sloan 1996), then the intercept should be significantly different from zero. The intercept of the hedge portfolio indicates whether abnormal returns can be obtained buying and selling short the extreme portfolios formed with the variable of interest (in this case, conservatism). If conservatism results in lower cost of capital, we expect the intercept $\alpha$ of the hedge portfolio to be significantly negative.

\subsection{Two stage cross sectional regressions}

The prior tests do not allow us to disentangle whether market participants reward conditionally conservative firms or whether they do not fully impound differences in 
conditional conservatism into prices. To test whether conservatism is a priced risk factor, we use a two stage cross sectional regression approach, where we regress the excess returns of a set of test assets on the Fama French risk factors betas, a momentum beta, and the beta of a conservatism factor (Cochrane 2005). The idea is to check whether the hypothesized factor contributes to explain the cross section of asset returns. Using the prior data, each month, we form a factor mimicking portfolio called AMC (Aggressive minus Conservative). To calculate AMC, at the beginning of every month, we sort firms into Conservatism deciles. For example, for April of year $t$, firms are ranked into deciles based on the Conservatism value calculated using annual data for fiscal year ends between January and December of year $t \quad 1$. Monthly returns of each decile portfolio are calculated as the value weighted average of excess returns of the firms in the portfolio. To construct AMC, each month, the value weighted return of stocks in the highest three deciles of Conservatism is subtracted from the value weighted return on stocks in the lowest three deciles of Conservatism. That is, we buy the three deciles with the least conservative firms and sell the three deciles with the most conservative firms. We use value weighted portfolios to reduce the upward biases in returns that arise when rebalancing equal weight portfolios (Blume and Stambaugh 1983).

In the first stage of the test, we incorporate the AMC factor mimicking portfolio to the Fama and French (1993) three factor model plus a momentum factor to estimate the betas from each factor. The augmented model is as follows:

$$
\begin{aligned}
R_{P, t} \quad R_{F, t}= & \alpha+\beta_{\mathrm{RM}-\mathrm{RF}}\left(R_{M, t} \quad R_{F, t}\right)+\beta_{S M B} S M B_{t}+\beta_{H M L} H M L_{t} \\
& +\beta_{U M D} U M D_{t}+\beta_{A M C} A M C_{t}+\mu_{t}
\end{aligned}
$$

In the second stage, we regress mean excess returns on the risk factor betas estimated from Eq. 3 using the following model:

$$
R_{P, t} \quad R_{F, t}=\alpha+\delta_{1} \hat{\beta}_{\mathrm{RM}-\mathrm{RF}}+\delta_{2} \hat{\beta}_{S M B}+\delta_{3} \hat{\beta}_{H M L}+\delta_{4} \hat{\beta}_{U M D}+\delta_{5} \hat{\beta}_{A M C}+\mu_{t}
$$

Because betas in the second stage regression are estimated betas (derived from Eq. 3), there is a potential error in variables problem that may bias the standard errors of the second stage regression coefficients. To mitigate this concern, we apply the correction proposed by Shanken (1992) to adjust for the overstated precision of the Fama MacBeth standard errors. Equation (3) is estimated in time series at the portfolio level. We follow standard finance literature and use as test assets the 25 size and book to market portfolios created by Fama and French (1993). ${ }^{6}$ These 25 portfolios have become the standard benchmark in testing competing asset pricing models (Petkova 2006). These test assets are extremely challenging and for this reason they are widely used. We also use as test assets a set of 25 portfolios from the intersection of the quintiles of Size with the quintiles of Momentum. ${ }^{7}$ If conditional conservatism is a priced risk factor, then, portfolios with a larger $\hat{\beta}_{A M C}$ should obtain larger abnormal returns. If this is the case, the $\delta_{5}$ coefficient in Eq. 4 is predicted to be significantly positive.

\footnotetext{
${ }^{6}$ The data are available at http://mba.tuck.dartmouth.edu/pages/faculty/ken.french/data library.html.

${ }^{7}$ In additional robustness tests, we also use 25 size-conservatism portfolios and 100 conservatism portfolios.
} 
3.3 Developing and assessing the construct validity of a firm specific measure of conditional conservatism (Conservatism)

We construct our empirical proxy of conditional conservatism based on the firm year specific ratio of conditional conservatism (CR) developed by Callen et al. (2010). ${ }^{8}$ CR captures the percentage of a shock to current and future firm earnings that is incorporated into current period unexpected earnings. Callen et al. (2010) base their measure on the Vuolteenaho (2002) return decomposition model. Vuolteenaho (2002) shows that shocks to returns can be decomposed into: (1) shocks to current and future dividends (or cash flows) and (2) shocks to current and future discount rates. Replacing dividends with earnings through the clean surplus relation, shocks to returns can be expressed in terms of shocks to current and expected future earnings and shocks to current and future discount rates:

$$
r_{t} \quad E_{t-1}\left(r_{t}\right)=\mathrm{Ne} \quad \mathrm{Nr}
$$

where $r$ is the market rate of return, $\mathrm{Ne}$ is earnings news (shocks), and $\mathrm{Nr}$ is discount rates news (shocks). The above equation shows that unexpected revision to current stock returns increases with earnings news and decreases with discount rate news. $\mathrm{CR}$ measures the relation between earnings news $(\mathrm{Ne})$ and current period unexpected earnings. It captures the fact that the asymmetric properties of conservative accounting, along with the existence of alternative non accounting sources of information, generate nonlinear relations between revisions to equity returns and earnings news. CR measures the asymmetry between gain and loss recognition timeliness because in the case of adverse earnings news, a higher proportion of the news is recognized in current earnings.

To obtain proxies for earnings news and current period unexpected earnings, Callen et al. implement the Vuolteenaho (2002) decomposition using a log linear vector autoregressive (VAR) model consisting of the following system of equations, where the firm subscript, $i$, is understood:

$$
\begin{gathered}
r_{t}=\alpha_{1} r_{t-1}+\alpha_{2} \text { roe }_{t-1}+\alpha_{3} \text { bm }_{t-1}+\eta 1_{t} \\
\text { roe }_{t}=\beta_{1} r_{t-1}+\beta_{2} \text { roe }_{t-1}+\beta_{3} \text { bm }_{t-1}+\eta 2_{t} \\
\text { bm }_{t}=\delta_{1} r_{t-1}+\delta_{2} \text { roe }_{t-1}+\delta_{3} \text { bm }_{t-1}+\eta 3_{t}
\end{gathered}
$$

using the VAR matrix of estimated coefficients from the system of Eqs. 6, 7, and 8 and the vectors of residuals $\eta$, Callen et al. arrive at the following expressions for the unexpected shock to returns, discount rate news $(\mathrm{Nr})$, and earnings news $(\mathrm{Ne})$ :

$$
\begin{gathered}
r_{t} \quad E_{t-1}\left(r_{t}\right)=\eta 1_{, t} \\
N r_{t}=e 1^{\prime} \rho A(I \quad \rho A)^{-1} \eta_{i, t}
\end{gathered}
$$

\footnotetext{
${ }^{8}$ There is an alternative firm-year specific measure of conservatism (c-score) developed by Khan and Watts (2009). Although it is a perfectly valid measure, we choose not to use c-score in our tests because it is a linear combination of size, market-to-book, and leverage. These three variables are proxies for risk and the results could be attributed to c-score being a proxy for these three risk factors.
} 


$$
N e_{t}=e 2^{\prime}\left(\begin{array}{ll}
I & \rho A
\end{array}\right)^{-1} \eta_{i, t}
$$

where $A$ is the matrix of estimated coefficients from system of Eqs. 6, 7, and 8. $e 1$ ' and $e 2^{\prime}$ are vectors equal to $[1,0,0]$ and $[0,1,0]$ respectively. $I$ is the identity matrix. $\rho$ is a constant equal to 0.967 , and $\eta_{i, t} \quad\left[\eta 1_{i, t}, \eta 2_{i, t}, \eta 3_{i, t}\right]^{\prime}$. Finally, taking the residuals from Eq. 7 as their proxy for current period unexpected earnings, they empirically estimate the level of conditional conservatism as the ratio of unexpected current earnings to total earnings news:

$$
\mathrm{CR}_{i, t}=\eta 2_{i, t} / N e_{i, t}
$$

Larger values of $\mathrm{CR}$ indicate greater conditional conservatism: in the event of a negative earnings shock, a larger part of the earnings shock $(\mathrm{Ne})$ is reflected in current period unexpected earnings $(\eta 2)$. In the extreme $(\mathrm{CR} 1)$, current period unexpected earnings fully reflect the earnings shock. Thus the ratio measures the proportion of the total shock to current and expected future earnings (cash flows) recognized in current year earnings. As stated in Callen et al. (2010), "by this criterion, firm $\mathrm{A}$ is more conservative than firm $\mathrm{B}$, if for a given negative (positive) shock to current and future expected cash flows, firm A recognizes more (less) of the shock in current year earnings than does firm B."

To compute CR we follow scrupulously the estimation details described in Callen et al. (2010). In particular, the return variable $r$ equals the log of one plus the annual return ending 3 months after closing minus the log of one plus the annualized three month $\mathrm{T}$ bill rate. The earnings variable roe is the log of one plus ROE minus the $\log$ of one plus the annualized 3 month $\mathrm{T}$ bill rate. ROE is computed as income before extraordinary items scaled by beginning book value of equity. The book to market variable $b m$ equals the log of the book to market ratio at year end. To control for industry effects, the VAR system is estimated for each Fama and French (1997) industry group using weighted least squares with one pooled regression per system equation. Each annual cross section is weighted equally by deflating the data by the number of firms in that year and all variables in the system are demeaned. ${ }^{9}$ Finally, we remove firms with market value of equity below $\$ 10$ million, financial firms (SIC 6000 6999), and observations in the top and bottom $1 \%$ of each variable. As in Callen et al. (2010), we drop firm year observations with a negative CR.

\subsubsection{Assessment of the construct validity of the conservatism proxy}

To capture persistence in firms' reporting choices, our conservatism proxy (Conservatism) is measured as the three year average of CR. ${ }^{10}$ To assess the validity of Conservatism as a proxy for conditional conservatism, we replicate the procedures and variable measurement in Callen et al. (2010) and construct the 3 year averages of $\mathrm{CR}$ for all non financial firms with the necessary data available in

\footnotetext{
${ }^{9}$ The precise estimation details are available in Callen and Segal (2009). We also appreciate the technical assistance provided by Dan Segal.

${ }^{10}$ All our inferences remain unchanged if we set the value of Conservatism equal to the firm-year specific CR. For the single-year CR, our descriptive statistics are virtually identical to those reported in Callen et al. (2010).
} 
Compustat and CRSP for the period 1975 2003. Our resulting sample contains 54,389 firm year observations, after deleting the top and bottom percentiles of CR. Table 1 contains sample descriptive statistics. Although our sample differs from the one used by Callen et al. (2010) and we measure the conservatism ratio as a 3 year average, our descriptive evidence is very similar to what they report. The mean (median) Conservatism is 0.47 (0.39) for our sample, while the mean (median) CR is $0.51(0.39)$ in the sample used by Callen et al., which spans the period 1962 2006. The interpretation of Conservatism is that, on average, a $47 \%$ of the shock to current and future earnings (the earnings news, $\mathrm{Ne}$ ) is incorporated into current unexpected earnings. As expected, total accruals are on average negative, due to the effect of depreciation and amortization charges. The market to book ratio is well above one, suggesting the presence of unconditional conservatism. Special items are on average negative, consistent with the results in Callen et al. (2010).

To assess the validity of our proxy, we regress the decile ranks of Conservatism on the economic determinants of conditional conservatism. In particular, we expect conditional conservatism to be positively related to (1) contracting pressures and (2) litigation risk and negatively related to (3) unconditional conservatism, (4) total accruals, and (5) special items.

As highlighted by Watts (2003) and demonstrated by Qiang (2007), Ball et al. (2008), and García Lara et al. (2009b), among others, debt contracting is one of the main determinants of conditional conservatism. We use leverage as a proxy for the debt related pressures faced by the firm. Consequently, if Conservatism is a good proxy for conditional conservatism we expect a positive association between our conservatism measure and leverage. Regarding litigation risk, Watts (2003) points at litigation risk as one of the main determinants of conditional conservatism, and empirical evidence by Qiang (2007) and García Lara et al. (2009b) supports this hypothesis using different proxies for conditional conservatism and litigation risk. As a proxy for equity contracting pressures and litigation risk, we follow Callen et al. (2010) and use the standard deviation of returns. This is a measure of operating risk. Firms with higher operational uncertainty are expected to be subject to greater shareholder monitoring and litigation risk. Thus, if Conservatism correctly captures variation in conditional conservatism, we should find a positive association between the standard deviation of returns and Conservatism. With respect to unconditional conservatism, we follow most of prior research and measure it using the market to book ratio. As an additional proxy for unconditional conservatism that captures ex ante conservative accounting choices, we also employ the Penman and Zhang (2002) C score. Following Beaver and Ryan (2005), we expect a negative association between conditional and unconditional conservatism. Finally, prior literature expects more conditionally conservative firms to have more negative average accruals (Givoly and Hayn 2000) and conditional conservatism to be also applied through special items (Pope and Walker 1999). Thus we expect a negative association between total accruals and Conservatism and between special items and Conservatism.

We measure these variables as follows: leverage is the ratio of interest bearing debt to total assets. Returns volatility is the three year average of the standard deviation of 1 year of daily stock returns. Market to book is the market to book 
Table 1 Descriptive statistics of the conservatism proxy and the variables of interest for the constructvalidity tests

\begin{tabular}{lclccc}
\hline Variable description & Mean & St. Dev & p25 & p50 & p75 \\
\hline Conservatism & 0.47 & 0.36 & 0.28 & 0.39 & 0.54 \\
Leverage & 0.22 & 0.17 & 0.07 & 0.21 & 0.34 \\
Total accruals & 0.03 & 0.09 & 0.08 & 0.04 & 0.01 \\
Market-to-book & 2.15 & 1.69 & 1.08 & 1.65 & 2.61 \\
Special items & 0.01 & 0.03 & 0.00 & 0.00 & 0.00 \\
Returns volatility & 0.03 & 0.01 & 0.02 & 0.03 & 0.04 \\
Size & 5.33 & 1.76 & 3.92 & 5.10 & 6.56 \\
Beta & 1.09 & 0.59 & 0.71 & 1.05 & 1.41 \\
BM & 0.54 & 0.65 & 0.96 & 0.50 & 0.08 \\
Momentum & 0.17 & 0.48 & 0.13 & 0.10 & 0.36 \\
PZ C-score & 0.21 & 0.53 & 0.00 & 0.05 & 0.21 \\
Bid-Ask spread & 3.60 & 2.14 & 2.07 & 3.05 & 4.61 \\
CFO volatility & 7.56 & 8.17 & 3.90 & 6.10 & 9.23 \\
Smoothing & 0.62 & 0.42 & 0.81 & 0.54 & 0.33 \\
Forecast error & 0.29 & 0.67 & 0.03 & 0.07 & 0.22 \\
Forecast variability & 0.08 & 0.12 & 0.02 & 0.04 & 0.10 \\
\hline
\end{tabular}

The sample contains 54,389 firm-year observations for the period 1975-2003. Conservatism is the threeyear average of the firm-year specific proxy of conditional conservatism developed by Callen et al. (2010). Unless otherwise indicated, the following variables are measured at the end of the fiscal year. Leverage is the ratio of interest-bearing debt to total assets. Total accruals equals [ $(\Delta$ current assets

$\Delta$ cash $) \quad(\Delta$ current liabilities $\Delta$ short term debt) depreciation]/average assets. Market-to-book is the market-to-book value of equity ratio. Special items equal special items scaled by average total assets. Returns volatility is the three-year average of the standard deviation of 1 year of daily stock returns. Size is the log of the market value of equity. Beta is the slope coefficient from the regression of a firm's monthly excess returns on the monthly value-weighted market excess return (from the CRSP monthly index file) over a rolling 60-month (minimum 24 months) window ending in the current fiscal year. BM is the log of the book-to-market value of equity ratio. Momentum is the buy and hold return for the 11month period ending 1 month prior to at the end of the year. PZ C-score is the measure of unconditional conservatism developed by Penman and Zhang (2002) that captures the firm's choice of accounting methods that keep the book value of net assets relatively low (only available for 43,913 observations). Bid-Ask spread is the average daily bid-ask spread over the fiscal year scaled by price, as a percentage. CFO volatility is the standard deviation of the firm's rolling 10 year cash flows from operations scaled by beginning total assets, as a percentage. Smoothing is the ratio of earnings volatility to CFO volatility multiplied by 1 , where earnings volatility is the standard deviation of the firm's rolling ten-year earnings before extraordinary items scaled by beginning total assets (Smoothing and CFO volatility are only available for 25,628 observations). Forecast error is the earnings-per-share forecast error measured as the absolute value of the difference between the mean forecast EPS and the actual EPS, scaled by the actual EPS. The forecast is taken in the 10th month of the fiscal year from IBES summary data. Forecast variability is the standard deviation of the earnings forecasts. We impose a minimum of three earnings forecasts per firm-year. Forecast error and Forecast variability are only available for 15,388 observations. Forecast error is winsorized at the 95th percentile. The rest of continuous variables are winsorized annually at the 1st and 99th percentiles to avoid the effect of influential observations

value of equity ratio. Total accruals equals $[(\Delta$ current assets $\quad \Delta$ cash $) \quad(\Delta$ current liabilities $\Delta$ short term debt) depreciation]/average assets. Special items equal special items scaled by average total assets. Finally, we also control for size, defined as the $\log$ of the market value of equity. 
Table 2 Construct-validity tests of the conservatism proxy

\begin{tabular}{lcccccc}
\hline Regression of decile rankings of Conservatism & on several determinants of conservatism \\
\hline Dep. var: Conservatism deciles & Coeff. & \multicolumn{1}{l}{$t$-stat } & $p$-val & Coeff. & $t$-stat & $p$-val \\
\hline Constant & 5.14 & 39.51 & 0.00 & 5.11 & 36.45 & 0.00 \\
Leverage & 1.64 & 12.44 & 0.00 & 1.44 & 10.50 & 0.00 \\
Total accruals & 2.19 & 12.27 & 0.00 & 2.20 & 11.54 & 0.00 \\
Market-to-book & 0.18 & 8.06 & 0.00 & 0.16 & 6.96 & 0.00 \\
Special items & 3.52 & 3.80 & 0.00 & 3.82 & 4.36 & 0.00 \\
Returns volatility & 6.26 & 2.60 & 0.01 & 8.24 & 3.31 & 0.00 \\
Size & 0.01 & 0.46 & 0.64 & 0.01 & 0.56 & 0.57 \\
PZ C-score & & & & 0.19 & 3.36 & 0.00 \\
$R$-sqr & 0.03 & & & 0.03 & & \\
Nobs & 54,389 & & & 43,913 & &
\end{tabular}

The dependent variable is the annual decile rankings of Conservatism. The rest of variables are defined in Table 1

Coefficients are based on pooled regressions. The $t$-statistics are based on standard errors clustered at the firm and year level (Petersen 2009), which are robust to both heteroskedasticity and within-firm serial correlation. All the $p$-values are based on two-tailed tests

Table 2 presents the results of a regression of the decile ranks of Conservatism on leverage, total accruals, the market to book ratio, special items, the standard deviation of returns, size, and the Penman and Zhang (2002) C Score. We employ deciles of Conservatism to reduce measurement error, but the inferences are similar when we use Conservatism. Following Petersen (2009), we estimate this regression in a pooled fashion and report $t$ statistics based on standard errors that are robust to heteroskedasticity, serial and cross sectional correlation with a two dimensional cluster at the firm and year level. ${ }^{11}$ All coefficient estimates are significant except size, for which we did not have an ex ante prediction, given that prior literature offers conflicting views on the relation between firm size and conditional conservatism. All other coefficients behave as expected: we find a negative coefficient for total accruals, market to book ratio, special items, and unconditional conservatism (as measured through the C Score) and a positive coefficient for leverage and the standard deviation of returns. ${ }^{12}$ These results suggest that Conservatism is a good proxy for conditional conservatism. ${ }^{13}$

\footnotetext{
11 We obtain similar inferences using the Fama and MacBeth (1973) procedure. The results are also robust to the inclusion of industry indicator variables.

12 Notice that special items are on average negative. Higher special items are associated with higher conservatism. Therefore, the coefficient on special items is expected to be negative.

13 In additional tests to validate Conservatism, we create four portfolios of firms ranked according to Conservatism. For each portfolio, we estimate the cross-sectional models of (a) asymmetric persistence in income changes (Basu 1997; Ball and Shivakumar 2005) and (b) asymmetric earnings timeliness to good and bad news (Basu 1997). Unreported results show that conservatism measures drawn from these models increase as we move from the least to the most conservative portfolio according to our Conservatism measure, confirming that our measure of conditional conservatism correctly classifies firms according to their level of conservative accounting.
} 
Table 3 Asset pricing tests-descriptive statistics

Panel A: Summary statistics of the factors

\begin{tabular}{lllllllll}
\hline Variable & Obs & Mean & St. Dev. & \multicolumn{1}{l}{ Min } & P50 & Max & $t$-stat & $p$-val \\
\hline$R_{M} \quad R_{F}$ & 348 & 0.63 & 4.48 & 23.13 & 1.01 & 12.43 & 2.63 & 0.01 \\
SMB & 348 & 0.31 & 3.27 & 16.70 & 0.28 & 22.18 & 1.76 & 0.08 \\
HML & 348 & 0.42 & 3.13 & 12.80 & 0.39 & 13.80 & 2.51 & 0.01 \\
UMD & 348 & 0.88 & 4.26 & 25.05 & 0.99 & 18.40 & 3.87 & 0.00 \\
AMC & 348 & 0.20 & 1.25 & 4.13 & 0.16 & 4.20 & 2.99 & 0.00
\end{tabular}

Panel B: Pearson correlation matrix of the factors

\begin{tabular}{lllll}
\hline & $R_{M} \quad R_{F}$ & SMB & HML & UMD \\
\hline SMB & 0.23 & & & \\
& $<.0001$ & & & \\
HML & 0.47 & 0.35 & & \\
& $<.0001$ & $<.0001$ & 0.13 & \\
UMD & 0.01 & 0.15 & 0.01 & 0.13 \\
& 0.85 & 0.01 & 0.27 & 0.01 \\
AMC & 0.08 & 0.12 & $<.0001$ & \\
& 0.12 & 0.03 & & \\
\end{tabular}

The sample covers the months from Jan. 1, 1976 to Dec. 31, 2004. The panels show summary statistics of the three Fama-French factors, a momentum factor UMD, and a conservatism factor AMC. $R_{M} \quad R_{F}$ is excess return on the value-weighted market portfolio. SML is the value-weighted size-mimicking portfolio return. HML is the value-weighted BM-mimicking portfolio return. UMD is the value-weighted momentum-mimicking portfolio return. $R_{M} \quad R_{F}, \mathrm{SMB}$, HML, and UMD are obtained directly from WRDS. AMC (Aggressive minus Conservative) is a factor-mimicking portfolio for conditional conservatism. To construct AMC, each month, the value-weighted return of stocks in the highest three deciles of Conservatism is subtracted from the value-weighted return on stocks in the lowest three deciles of Conservatism. Italic values indicate $p$-values

\section{Asset-pricing tests data and results}

We use Compustat to extract accounting data and CRSP to extract stock market data. Our sample period spans 29 years, $t \quad 19762004$ (348 months from January 1976 to December 2004). ${ }^{14}$ Table 3 reports descriptive evidence of the data used to run the asset pricing tests. Panels A and B show summary statistics of the three Fama French factors ( $R_{M} \quad R_{F}$, SMB and HML), a momentum factor (UMD), and the conservatism factor AMC (Aggressive minus Conservative). AMC is the factor mimicking portfolio for conditional conservatism. To construct AMC, each month, the value weighted return of stocks in the highest three deciles of Conservatism is subtracted from the value weighted return on stocks in the lowest three deciles of Conservatism. $R_{M} \quad R_{F}$, SMB, HML, and UMD are obtained directly from the Fama French database on WRDS.

14 The first year is 1976 because we start measuring Conservatism in the previous year. 
Table 3 Panel A shows descriptive statistics for the AMC factor and for the three Fama French factors and the momentum factor. This evidence permits examining whether there is a significant unconditional time series mean risk premium on the factors. The mean monthly time series premium for the AMC factor of $0.20 \%$ implies a mean annual risk premium of about $2.5 \%$, which is statistically different from zero. This evidence on the time series mean of the AMC factor provides an initial estimate of the factor premium. The fact that AMC is significant indicates that AMC is likely to be priced (Shanken and Weinstein 2006). As expected, all other factors also have positive means (significantly different from zero). Panel B presents the correlation matrix. The only significant correlation between the AMC factor and the other factors is with the BM mimicking portfolio (HML), with a correlation of 0.27 ( $p$ val <.001). This is not unexpected, as to the extent that BM is a (noisy) proxy of unconditional conservatism and unconditional conservatism is negatively associated to conditional conservatism, sorting stocks on BM may partially sort stocks on Conservatism as well. The rest of correlations are similar to those reported in recent studies (Petkova 2006; Core et al. 2008).

Table 4 presents results of the estimation of Eq. 1. Parameter estimates are time series averages of the parameters from 348 monthly cross sectional regressions. Consistent with prior research the coefficient on Beta is insignificant, and Size (BM, Momentum) is negatively (positively) related to excess returns (Fama and French

Table 4 Cross-sectional regressions of future firm returns

Cross-sectional regression of monthly value-weighted future excess returns on firm characteristics and conservatism (average coefficients of 348 monthly regressions)

\begin{tabular}{|c|c|c|c|c|c|c|}
\hline & Intercept & Beta & Size & BM & Momentum & Conservatism \\
\hline Estimate & 1.64 & 0.07 & 0.09 & 0.26 & 0.27 & 0.04 \\
\hline$t$-stat & (4.98) & $(0.41)$ & (1.88) & $(3.10)$ & $(2.91)$ & (4.73) \\
\hline$p$-val & $<0.01$ & 0.68 & 0.06 & $<0.01$ & $<0.01$ & $<0.01$ \\
\hline Avg. $R$-sqr & 0.04 & & & & & \\
\hline Nobs & 348 & & & & & \\
\hline
\end{tabular}

Each month from Jan. 1, 1976 to Dec. 31, 2004, the cross-section of future monthly excess returns is regressed on beta, size, BM, Momentum, and Conservatism. We match annual estimates of the explanatory variables to monthly returns in the next 12 months starting four months after the fiscal yearend. That is, for December fiscal year-ends, we collect monthly returns from April of year $t+1$ to March of year $t+2$. Monthly excess returns are measured in percentages and are calculated as the raw stock return less the risk-free rate. Beta is the slope coefficient from the regression of a firm's monthly excess returns on the monthly value-weighted market excess return (from the CRSP monthly index file) over a rolling 60-month (minimum 24 months) window ending in the current fiscal year. Size is the natural log of market value of equity measured at the end of the current fiscal year. BM is the natural $\log$ of the ratio of book value of equity to market value of equity measured at the end of the current fiscal year. Momentum is the buy and hold return for the 11-month period ending 1 month prior to at the end of the year. Conservatism is the monthly decile ranks of the three-year average of the firm-year specific proxy of conditional conservatism developed by Callen et al. (2010). Parameter estimates are time-series averages of the parameters from the 348 monthly cross-sectional regressions. The reported $t$-statistics are calculated from the standard errors of these monthly averages following the Fama and MacBeth (1973) procedure. Continuous variables are winsorized annually at the 1st and 99th percentiles 
1992). We report a negative relation between conditional conservatism and average realized stock returns (Conservatism 0.04, $t$ stat 4.73). In terms of economic significance, this coefficient indicates that moving from the bottom to the top decile of Conservatism decreases the cost of equity capital by $4.14 \%$ per year. This provides initial evidence that conditional conservatism predicts future excess returns. However, as noted by Core et al. (2008), among others, the fact that Conservatism is negative and statistically significant in model (1) does not necessarily imply that Conservatism is a priced risk factor. This method does not permit disentangling whether the observed effect is driven by investors being rewarded for risk or simply by mispricing.

The results of estimating Eq. 2 are reported in Table 5 Panels A to C. We first run the model including just an intercept, to see whether firms in the least conservative portfolios obtain greater excess returns on average. This is indeed the case, as for the hedge portfolio the intercept is 0.18 ( $t$ stat 1.95), meaning that the trading strategy of buying the more conservative firms and selling short the least conservative ones obtains an average raw return of $0.18 \%$ per month, consistent with the prior evidence of a mean annual premium of around $2 \%$. This negative coefficient on the hedge portfolio suggests that firms with high Conservatism earn smaller returns than firms with low Conservatism. When we introduce the excess returns on the market portfolio in the model, the intercept is still significant, showing that the hedge portfolio would obtain a negative abnormal CAPM adjusted return of $0.16 \%$ per month. Finally, when we introduce all the Fama French factors plus the momentum factor, the intercept is once more significant and of a similar magnitude to what was previously reported. The negative abnormal return of the hedge portfolio is $0.25 \%$ per month; this means that the strategy of buying a portfolio of firms in the top decile of conservatism and selling the bottom decile generates abnormal annual returns of $3.02 \%$. These results show investors reward more conditionally conservative firms with a smaller cost of capital.

As previously detailed, we carry out an additional asset pricing test to ensure that the prior findings are indicative of conservatism being a priced risk factor. Table 6 contains the results of the two stage estimation method explained in Sect. 3.2 above. Panels A1, B1, and C1 provide evidence on the first stage regression for the three sets of portfolios. For reference, Panel A1 shows the results of estimating Eq. 3 without including the conservatism factor. Panels $\mathrm{B} 1$ and $\mathrm{C} 1$ incorporate the conservatism factor (AMC). The coefficients for $R_{M} \quad R_{F}$, SMB, HML, and UMD are similar to those reported by prior work. Regarding the coefficients on the AMC factor, they are significantly positive both in Panel B1 (0.09, $t$ stat 3.07) and Panel C1 (0.08, $t$ stat 2.65). In all three panels we report the Gibbons et al. (1989) test on whether the estimated intercepts are jointly zero. The GRS test statistic should not be rejected if the factors explain excess returns and the model is correctly specified. The GRS test statistic is significantly different from zero in all panels, but a more detailed analysis of the individual intercepts reveals that only $3(2,3)$ out of the total intercepts are significantly different from zero in Panel A1 (B1, C1). These findings coincide with those reported in other studies (Fama and French 1993; Petkova 2006; Chordia and Shivakumar 2006; Core et al. 2008). 
Table 5 Conservatism and future portfolio returns

Time-series regressions of monthly value-weighted portfolio returns on the three Fama-French factors and a momentum factor (348 months)

\begin{tabular}{|c|c|c|c|c|c|c|}
\hline Conservatism decile & Intercept & $R_{M} \quad R_{F}$ & SMB & HML & UMD & $R$-squared \\
\hline \multicolumn{7}{|l|}{ Panel A: } \\
\hline Low conservatism: 1 & 1.02 & & & & & \\
\hline$t$-stat & $(3.71)^{\mathrm{c}}$ & & & & & \\
\hline High conservatism: 10 & 0.84 & & & & & \\
\hline$t$-stat & $(3.11)^{\mathrm{c}}$ & & & & & \\
\hline Hedge: $10-1$ & 0.18 & & & & & \\
\hline$t$-stat & $(1.95)^{\mathrm{a}}$ & & & & & \\
\hline \multicolumn{7}{|l|}{ Panel B: } \\
\hline Low conservatism: 1 & 0.37 & 1.04 & & & & 0.82 \\
\hline$t$-stat & $(3.11)^{\mathrm{c}}$ & $(39.79)^{\mathrm{c}}$ & & & & \\
\hline High conservatism: 10 & 0.21 & 1.01 & & & & 0.80 \\
\hline$t$-stat & $(1.69)^{\mathrm{a}}$ & $(37.73)^{\mathrm{c}}$ & & & & \\
\hline Hedge: $10-1$ & 0.16 & 0.03 & & & & 0.01 \\
\hline$t$-stat & $(1.75)^{\mathrm{a}}$ & $(1.32)$ & & & & \\
\hline \multicolumn{7}{|l|}{ Panel C: } \\
\hline Low conservatism: 1 & 0.28 & 1.00 & 0.52 & 0.13 & 0.11 & 0.92 \\
\hline$t$-stat & $(3.29)^{\mathrm{c}}$ & $(49.73)^{\mathrm{c}}$ & $(20.13)^{\mathrm{c}}$ & $(4.45)^{\mathrm{c}}$ & $(6.04)^{\mathrm{c}}$ & \\
\hline High conservatism: 10 & 0.03 & 1.03 & 0.54 & 0.33 & 0.16 & 0.93 \\
\hline$t$-stat & $(0.37)$ & $(55.48)^{\mathrm{c}}$ & $(22.18)^{\mathrm{c}}$ & $(11.96)^{\mathrm{c}}$ & $(9.17)^{\mathrm{c}}$ & \\
\hline Hedge: $10-1$ & 0.25 & 0.04 & 0.01 & 0.20 & 0.05 & 0.13 \\
\hline$t$-stat & $(2.70)^{\mathrm{c}}$ & $(1.68)^{\mathrm{a}}$ & $(0.44)$ & $(6.09)^{\mathrm{c}}$ & $(2.27)^{\mathrm{b}}$ & \\
\hline
\end{tabular}

Each month, from Jan. 1, 1976 to Dec. 31, 2004 (348 months), all firm-years in the sample are ranked into 10 deciles based on their Conservatism value. Portfolios of stocks are then formed for each Conservatism decile. The table reports the estimated coefficients and $t$-statistics of portfolio regressions of valueweighted portfolio excess returns on the three Fama-French factors and a momentum factor UMD. $R_{M}$ $R_{F}$ is excess return on the value-weighted market portfolio. Excess returns equal the value-weighted return on the portfolios less the risk free rate. SML is the value-weighted size-mimicking portfolio return. HML is the value-weighted BM-mimicking portfolio return. UMD is the value-weighted momentum-mimicking portfolio return. $R_{M} \quad R_{F}$, SMB, HML, and UMD are obtained directly from WRDS. Monthly returns are measured in percentages. Panel A reports the parameter estimates from a regression of the portfolio excess returns on an intercept only. Panel B reports the parameter estimates from a regression of the portfolio excess returns on an intercept and the market portfolio. Panel $\mathrm{C}$ reports the parameter estimates from a regression of the portfolio excess returns on an intercept and all the Fama-French factors plus a momentum factor. Superscripts a, b, c indicate significance at the 10, 5, 1 percent level, respectively

The regression coefficients from this model cannot be directly interpreted as evidence that the factor is or not priced. These coefficients simply reflect that the test assets have exposure to the factors. The results of the second step regression (Eq. 4), where we directly analyze whether AMC is a priced factor, are presented in Table 6, Panels A2, B2, and C2. The coefficients for the three Fama French factors 
Table 6 Two-stage cross-sectional regressions

First stage: Portfolio time-series regressions of contemporaneous excess returns on factor returns

\begin{tabular}{|c|c|c|c|c|c|c|c|}
\hline & Intercept & $R_{M} \quad R_{F}$ & SMB & HML & UMD & AMC & Avg $R$-sqr \\
\hline \multicolumn{8}{|c|}{ Panel A1: Fama-French 25 Size-BM portfolios. Average factor loadings } \\
\hline Coeff. & 0.01 & 1.03 & 0.49 & 0.31 & 0.03 & & 0.90 \\
\hline$t$-stat & $(0.23)$ & (74.19) & (4.97) & (3.54) & (4.61) & & \\
\hline$p$-val & 0.82 & $<.0001$ & $<.0001$ & 0.00 & $<.0001$ & & \\
\hline$G R S$-stat & 2.59 & & & & & & \\
\hline$G R S p$-val & $<0.01$ & & & & & & \\
\hline \multicolumn{8}{|c|}{ Panel B1: Fama-French 25 Size-BM portfolios. Average factor loadings } \\
\hline Coeff. & 0.01 & 1.04 & 0.49 & 0.32 & 0.03 & 0.09 & 0.91 \\
\hline$t$-stat & $(0.45)$ & $(74.67)$ & $(4.96)$ & (3.65) & (4.87) & (3.07) & \\
\hline$p$-val & 0.66 & $<.0001$ & $<.0001$ & 0.00 & $<.0001$ & 0.01 & \\
\hline$G R S$-stat & 2.24 & & & & & & \\
\hline$G R S p$-val & $<0.01$ & & & & & & \\
\hline \multicolumn{8}{|c|}{ Panel C1: Fama-French 25 Size-Momentum portfolios. Average factor loadings } \\
\hline Coeff. & 0.05 & 1.04 & 0.45 & 0.22 & 0.14 & 0.08 & 0.90 \\
\hline$t$-stat & $(1.17)$ & $(56.25)$ & $(5.12)$ & $(5.34)$ & $(1.71)$ & $(2.65)$ & \\
\hline$p$-val & 0.25 & $<.0001$ & $<.0001$ & $<.0001$ & 0.10 & 0.01 & \\
\hline$G R S$-stat & 4.43 & & & & & & \\
\hline$G R S p$-val & $<0.01$ & & & & & & \\
\hline
\end{tabular}

Second stage: average coefficients of 348 monthly cross-sectional regressions of portfolio returns on factor loadings

\begin{tabular}{|c|c|c|c|c|c|c|c|}
\hline \multicolumn{8}{|c|}{$R_{P, t} \quad R_{F, t}=\alpha+\delta_{1} \hat{\beta}_{R M R F}+\delta_{2} \hat{\beta}_{S M B}+\delta_{3} \hat{\beta}_{H M L}+\delta_{4} \hat{\beta}_{U M D}+\delta_{5} \hat{\beta}_{A M C}+\mu_{t}$} \\
\hline & Intercept & $\beta_{\mathrm{RM} \mathrm{RF}}$ & $\beta_{\mathrm{SMB}}$ & $\beta_{\mathrm{HML}}$ & $\beta_{\mathrm{UMD}}$ & $\beta_{\mathrm{AMC}}$ & Avg $R$-sqr \\
\hline \multicolumn{8}{|c|}{ Panel A2: Fama-French 25 Size-BM portfolios } \\
\hline Coeff. & 1.01 & 0.30 & 0.26 & 0.50 & 2.07 & & 0.57 \\
\hline Shanken $t$-stat & $(2.47)$ & $(0.62)$ & $(1.34)$ & $(2.68)$ & $(2.47)$ & & \\
\hline$p$-val & 0.01 & 0.54 & 0.18 & 0.01 & 0.01 & & \\
\hline \multicolumn{8}{|c|}{ Panel B2: Fama-French 25 Size-BM portfolios } \\
\hline Coeff. & 0.38 & 0.29 & 0.29 & 0.52 & 3.43 & 0.46 & 0.61 \\
\hline Shanken $t$-stat & $(0.69)$ & $(0.47)$ & (1.45) & (2.73) & $(3.44)$ & $(2.09)$ & \\
\hline$p$-val & 0.49 & 0.64 & 0.15 & 0.01 & 0.00 & 0.04 & \\
\hline
\end{tabular}

Significance of the increase in $R$-square with respect to a model without $\beta_{\text {AMC }}: \quad p$-val: 0.062

Panel C2: Fama-French 25 Size-Momentum portfolios

$\begin{array}{llllllll}\text { Coeff. } & 1.14 & 0.38 & 0.46 & 0.35 & 0.8 & 0.85 & 0.69 \\ \text { Shanken } t \text {-stat } & (2.35) & (0.72) & (2.32) & (1.20) & (3.25) & (2.92) & \\ p \text {-val } & 0.02 & 0.47 & 0.02 & 0.23 & 0.00 & 0.00 & \end{array}$

Significance of the increase in $R$-square with respect to a model without $\beta_{\text {AMC }}$; $\quad p$-val: 0.058 
Table 6 continued

Panels A1, B1, and C1 present average factor loadings and average $R^{2}$ of time-series regressions of monthly contemporaneous portfolio excess stock returns (stock return minus the risk-free rate) on the three Fama-French factors, a momentum factor, and the AMC factor. The Size-BM and Size-Momentum portfolios are downloaded from the Fama-French database at http://mba.tuck.dartmouth.edu/pages/ faculty/ken.french/data library.html. The reported $t$-statistics are calculated from the portfolio-specific standard errors of the average parameters ( 25 coefficients on each variable). GRS statistic is the Gibbons et al. (1989) test on whether the estimated intercepts are jointly zero

Panels A2, B2, and C2 present average coefficients from 348 monthly cross-sectional regressions of excess value-weighted portfolio returns on portfolio factor loadings (i.e., the slope coefficients from the regressions in Panels A1, B1, and C1). The reported $t$-statistics are calculated from the standard errors of the average monthly parameter estimates following the Fama and MacBeth (1973) procedure

and momentum factor loadings are remarkably similar to those obtained by Core et al. (2008). Panel A2 shows the results of estimating model (4) without including the AMC factor loading. Panels B2 and C2 contain results for the full model. We can observe that the coefficient on $\beta_{\mathrm{AMC}}$ is significantly positive both in Panel B2

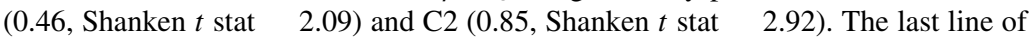
Panels B2 and C2 contains a test of the significance in the increase in $R^{2}$ when the model is compared with a simpler model excluding $\beta_{\mathrm{AMC}}$ as a regressor (that is, model A2 vs model B2). Although the increase in $R^{2}$ is modest, it is significant at conventional levels ( $p$ val 0.062 and 0.058 , respectively). This evidence is consistent with conservatism being a priced factor and with investors rewarding firms that report conditionally conservative accounting numbers with a reduced cost of capital (or alternatively, with investors penalizing firms with more aggressive reporting).

As an additional batch of robustness tests, we also use as test assets a set of 25 portfolios from the intersection of the quintiles of Size with the quintiles of Conservatism. Finally, we repeat the tests using as a test asset a set of 100 portfolios of Conservatism. The untabulated results are consistent across these different test asset specifications. For the 25 Size Conservatism portfolios, the coefficient on $\beta_{\text {AMC }}$ equals 0.21 (Shanken $t$ stat 2.77), and for the 100 Conservatism portfolios the coefficient on $\beta_{\text {AMC }}$ equals 0.19 (Shanken $t$ stat 2.72). Overall, the findings of our asset pricing tests are consistent with the analytical work of Guay and Verrecchia (2007) and Suijs (2008) in that, holding everything else constant, greater conditional conservatism is associated to lower cost of equity capital.

\section{Robustness tests}

5.1 Regression of implied cost of capital on conditional conservatism

An alternative test of the association between cost of capital and conditional conservatism is to use cost of capital estimates as measured by the expected rate of return implicit in analysts' forecasts. Similar to Francis et al. (2004), we model the association between implied cost of capital and Conservatism and controls as follows: 


$$
\Delta \log \left(1+r^{\mathrm{VL}}\right)=\alpha+\beta \Delta \text { Conservatism }+\delta \Delta \text { Risk Proxies }+\gamma \Delta \text { Controls }+\mu
$$

where $r^{\mathrm{VL}}$ is a proxy of implied cost of equity capital taken from the work of Brav et al. (2005). We estimate model (13) in changes rather than in levels because the changes specification reduces the bias introduced by omitted variables that remain relatively constant over a period of time such as industry variables and firm specific factors. The main coefficient of interest in Eq. 13 is $\beta$, which measures the association between changes in conditional conservatism (Conservatism) and changes in the ex ante cost of equity capital, controlling for changes in known risk factors and firm characteristics. If firms that increase conditional conservatism benefit from a lower implied cost of capital, $\beta$ is predicted to be negative and significant. $^{15}$

Unreported results show that the main coefficient of interest $\beta$ is significantly negative. Overall, these results show that firms reporting more conditionally conservative accounting numbers benefit from lower implied cost of equity capital, after controlling for known risk factors and earnings determinants, consistent with the evidence previously reported based on asset pricing tests. These results are also robust to controls for optimism in analysts' forecasts (Easton and Monahan 2005; Easton and Sommers 2007) and are available upon request.

\subsection{The link between conditional conservatism and future returns volatility}

We partly base our expectation that conditional conservatism contributes to reduce cost of capital on the analytical results of Suijs (2008), who shows that conservatism is expected to reduce cost of capital through a decrease in future returns volatility. To empirically address whether this hypothesis holds true in our sample, we analyze whether current conditional conservatism leads to reduced returns volatility over the coming year. To do so, we use the following model, which we estimate in a changes specification to reduce the effect of omitted variables bias:

$$
\Delta \text { Returns volatility }_{t+1}=\alpha+\beta \Delta \text { Conservatism }_{t}+\delta \Delta \text { Controls }_{t}+\mu_{t}
$$

where $\Delta$ Returns volatility $_{t+1}$ is the change in the log of the standard deviation of 1 year of daily stock returns ending at the end of fiscal year $t+1$. We apply the log transformation to Returns volatility to reduce the influence of the high skewness of this variable. $\Delta$ Conservatism is the change in our measure of conditional conservatism. As control variables, we consider the following determinants of future returns volatility: current returns volatility, the CAPM beta, size, the book to market ratio, momentum, the volatility of cash flows, the bid ask spread, and earnings smoothing.

\footnotetext{
15 In model (13) we consider the following risk proxies: (a) the CAPM beta, (b) market capitalization (size), (c) the book-to-market ratio, and (d) prior price momentum. These risk proxies are measured as previously described in Section 3. To isolate the discretionary component of the earnings attribute of interest, Conservatism, in model (13) we control for the same determinants used by Francis et al. (2004): (a) log of total assets, (b) cash flow variability, (c) sales variability, (d) length of the operating cycle, (e) incidence of negative earnings realizations, (f) intangibles intensity, (g) absence of intangibles, (h) capital intensity, and (i) dividend yield.
} 
Table 7, Panel A, contains the results of estimating Eq. 14. The coefficient on $\Delta$ Conservatism is negative and significant, confirming the analytical evidence in Suijs (2008) that current conditional conservatism reduces future returns volatility. The economic significance is such that a change in Conservatism equal to its inter

Table 7 Association of changes in Conservatism with changes in future returns volatility and earnings forecast errors

Panel A: Regression of the change in future returns volatility on change in Conservatism and controls

\begin{tabular}{lccc}
\hline Dep. var: $\Delta$ Returns volatility $_{t+1}$ & Coeff. & $t$-stat & $p$-val \\
\hline$\Delta$ Conservatism $_{t}$ & 0.024 & 2.38 & 0.02 \\
$\Delta$ Returns volatility $_{t}$ & 0.25 & 4.32 & 0.00 \\
$\Delta$ Beta $_{t}$ & 0.07 & 2.71 & 0.01 \\
$\Delta$ Size $_{t}$ & 0.01 & 0.50 & 0.62 \\
$\Delta$ BM $_{t}$ & 0.10 & 4.10 & 0.00 \\
$\Delta$ Momentum $_{t}$ & 0.03 & 1.74 & 0.08 \\
$\Delta$ Bid-Ask spread $_{t}$ & 0.02 & 2.50 & 0.01 \\
$\Delta$ CFO volatility $_{t}$ & 0.00 & 0.30 & 0.77 \\
$\Delta$ Smoothing $_{t}$ & 0.03 & 1.73 & 0.08 \\
Constant & 0.01 & 0.25 & 0.81 \\
Firm and year cluster & Yes & & \\
$R$-sqr & 0.05 & & \\
Nobs & 25,628 & &
\end{tabular}

Panel B: Regression of the change in analysts' forecast errors on change in Conservatism and controls

\begin{tabular}{lccc}
\hline Dep. var: $\Delta$ Forecast error & Coeff. & $t$-stat & $p$-val \\
\hline$\Delta$ Conservatism & 0.23 & 3.85 & 0.00 \\
$\Delta$ Forecast variability & 2.92 & 12.57 & 0.00 \\
$\Delta$ Size & 0.73 & 10.28 & 0.00 \\
Constant & 0.07 & 3.11 & 0.00 \\
Firm and year cluster & Yes & & \\
$R$-sqr & 0.07 & & \\
Nobs & 15,388 & & \\
\hline
\end{tabular}

Note for Panel A The dependent variable is the change in the log of future returns volatility, measured as the standard deviation of 1 year of daily stock returns ending at the end of the fiscal year $t+1$. The rest of variables are measured at the end of year $t$ and are defined in Table 1. The sample covers the period 1975-2003

Note for Panel B The dependent variable is the change in the log of analysts' earnings-per-share forecast errors. Forecast errors are measured as the absolute value of the difference between the mean forecast EPS and the actual EPS, scaled by the actual EPS. The forecasts are taken in the 10th month of the fiscal year from IBES summary data. Forecast variability is the standard deviation of the earnings forecasts. We impose a minimum of three earnings forecasts per firm-year. Size is the log of the market value of equity. The sample covers the period 1975-2003

In both panels, coefficients are based on pooled regressions. The $t$-statistics are based on standard errors clustered at the firm and year level (Petersen 2009), which are robust to both heteroskedasticity and within-firm serial correlation. All the $p$-values are based on two-tailed tests 
quartile range $(0.26)$ is associated with a reduction of $0.62 \%$ in daily returns volatility or $9.87 \%$ annualized. To put this value in perspective, notice that the annualized returns volatility is $47 \%$.

\subsection{The link between conditional conservatism and analysts' forecast errors}

Our expectation that conditional conservatism contributes to reduce cost of capital is also based on the analytical results of Guay and Verrecchia (2007), who show that conditional conservatism is expected to reduce cost of capital through a reduction in information uncertainty. This reduction in information uncertainty increases the precision with which investors can assess firm future cash flows, minimizing the discount markets apply to firm value. To empirically test this proposition, we analyze whether current conservatism, as measured through our Conservatism measure, leads to reduced analysts' forecast errors. To do so, we use the following model, which we estimate in a changes specification to reduce the effect of omitted variables bias:

$$
\Delta \text { Forecast error }=\alpha+\beta \Delta \text { Conservatism }+\delta \Delta \text { Controls }+\mu
$$

where $\Delta$ Forecast error is the change in the log of analysts' forecast error. The forecast error is measured as the absolute value of the difference between the mean forecast of earnings per share (EPS) and the actual EPS, scaled by the actual EPS. The forecast is taken in the 10th month of the fiscal year $t$ from IBES summary data. We apply the log transformation to Forecast error to reduce the influence of the high skewness of this variable. $\Delta$ Conservatism is the change in our measure of conditional conservatism. The set of controls includes size (a proxy for the number of analysts following) and forecast variability. Forecast variability is the standard deviation of the earnings forecasts. We impose a minimum of three earnings forecasts per firm year. Including additional control variables does not significantly affect the inferences.

Table 7, Panel B, contains the results of estimating Eq. 15. The reduced availability of forecast errors, together with the fact that we take changes in specifying the model, reduces the sample size to 15,388 observations. The coefficient on $\Delta$ Conservatism is negative and significant, confirming the analytical predictions of Guay and Verrecchia (2007) that conditional conservatism reduces investors' uncertainty, in this case by reducing analysts' forecast errors. The economic significance of our result is such that a change in Conservatism equal to its inter quartile range (0.26) is associated with an average reduction of $5.8 \%$ in the forecast error. To put this value in perspective, Table 1 shows that the average forecast error is $29 \%$.

\section{Summary and conclusions}

We empirically test the association between conditional conservatism and firm cost of equity capital. We run two sets of tests. First, we study if more conditionally conservative firms earn lower expected returns, using asset pricing tests commonly used in the finance literature. Second, we analyze the association between conditional conservatism and a measure of implied cost of capital. Both sets of tests produce corroborative evidence, showing a significant negative relation 
between conditional conservatism and cost of equity capital. This association is robust to the use of different testing methodologies and measurement procedures. Our evidence thus confirms the hypotheses of prior analytical research by Guay and Verrecchia (2007) and Suijs (2008), who argue that conservative reporting leads to increased information precision, increases in firm value, and reductions in firm cost of equity capital by reducing (1) uncertainty about the amount and distribution of future cash flows and (2) the volatility of future stock prices.

Our results add to a flourishing stream of empirical research in accounting conservatism that shows that conditional conservatism is associated to positive economic outcomes: lower information asymmetry problems (LaFond and Watts 2008), improved investment efficiency (Bushman et al. 2007; Ahmed and Duellman 2008), and better governance (Ahmed and Duellman 2007; García Lara et al. 2009a). The documented negative association between conditional conservatism and cost of capital adds some additional light to the regulatory debate on whether conservatism should be excluded from the desirable qualitative characteristics of accounting information. Our results indicate that, without properly enforced conservatism in accounting, firm disclosure is less precise. This, in turn, may lead to greater uncertainty, greater volatility of future prices, lower market values, and increased cost of capital.

Acknowledgments We are grateful to Alon Brav for providing access to the ex ante cost of equity capital estimates and to Dan Segal for his assistance in computing the CR conservatism proxy. We also appreciate the comments and suggestions from the editor (Doron Nissim), two anonymous referees, Gauri Bhat, Peter Easton, Miguel Ferreira, Jennifer Francis, Helena Isidro, Ryan LaFond, Angel León, Christian Leuz, Flora Muino, Per Olsson, Stephen Penman, Rodrigo Verdi, Katherine Schipper, Linda Vincent, and seminar participants at the 2009 Annual Meeting of the European Accounting Association, 2007 American Accounting Association Annual Meeting, ISCTE Business School, University of Alicante, University of Navarra (Pamplona), Tilburg University, University of Valencia, Universidad Carlos III de Madrid, Universidad de Murcia and Universidad Politécnica de Cartagena. We acknowledge financial assistance from the Spanish Ministry of Education and Science (ECO2008-06238/ECON and SEJ200767582/ECON), the European Commission INTACCT Research Training Network (MRTN-CT-2006035850), IESE Research Division, and the AECA Carlos Cubillo Chair in Accounting and Auditing.

\section{References}

Aboody, D., Hughes, J., \& Liu, J. (2005). Earnings quality, insider trading, and cost of capital. Journal of Accounting Research, 43(5), 651-673.

Ahmed, A. S., \& Duellman S. (2008). Evidence on the role of accounting conservatism in monitoring managers' investment decisions. Working paper, Texas A \& M University.

Ahmed, A. S., \& Duellman, S. (2007). Evidence on the role of accounting conservatism in corporate governance. Journal of Accounting and Economics, 43, 411-437.

Ball, R., Robin, A., \& Sadka, G. (2008). Is financial reporting shaped by equity markets or by debt markets? An international study of timeliness and conservatism. Review of Accounting Studies, 13, $168-205$.

Ball, R., \& Shivakumar, L. (2005). Earnings quality in UK private firms: Comparative loss recognition timeliness. Journal of Accounting and Economics, 39, 83-128.

Barth, M., Konchitchki, Y., \& Landsman, W. (2010). Cost of capital and earnings transparency. Working paper, Stanford University.

Basu, S. (1997). The conservatism principle and the asymmetric timeliness of earnings. Journal of Accounting and Economics, 24, 3-37. 
Battacharya, U., Daouk, H., \& Welker, M. (2003). The world price of earnings opacity. The Accounting Review, 78(3), 641-678.

Beaver, W. H., \& Ryan, S. G. (2005). Conditional and unconditional conservatism: concepts and modeling. Review of Accounting Studies, 10, 269-309.

Beekes, W., Pope, P. F., \& Young, S. (2004). The link between earnings timeliness, earnings conservatism and board composition: Evidence from the UK. Corporate Governance, 12(1), 47-51.

Blume, M., \& Stambaugh, R. F. (1983). Biases in computed returns: An application to the size effect. Journal of Financial Economics, 12, 387-404.

Botosan, C. A. (1997). Disclosure level and the cost of equity capital. The Accounting Review, 72(3), 323-349.

Botosan, C. A., \& Plumlee, M. A. (2002). A re-examination of disclosure level and the expected cost of equity capital. Journal of Accounting Research, 40, 21-41.

Brav, A., Lehavy, R., \& Michaely, R. (2005). Using expectations to test asset pricing models. Financial Management, 34(3), 31-64.

Bushman, R. M., Piotroski, J. D., \& Smith, A. J. (2007). Capital allocation and timely accounting recognition of economic losses: International evidence. Working Paper, University of Chicago.

Callen, J. L., \& Segal, D. (2009). A variance decomposition primer for accounting researchers. Journal of Accounting, Auditing and Finance, forthcoming.

Callen, J. L., Segal, D., \& Hope, O.-K. (2010). The pricing of conservative accounting and the measurement of conservatism at the firm-year level. Review of Accounting Studies, 15, 145-178.

Carhart, M. (1997). On the persistence of mutual fund performance. The Journal of Finance, 52, 57-82.

Chordia, T., \& Shivakumar, L. (2006). Earnings and price momentum. Journal of Financial Economics, $80,627-656$.

Cochrane, J. H. (2005). Asset pricing. Princeton, NJ: Princeton University Press.

Core, J., Guay, W., \& Verdi, R. (2008). Is accruals quality a priced risk factor? Journal of Accounting and Economics, 46, 2-22.

Daske, H., Hail, L., Leuz, C., \& Verdi, R. (2008). Mandatory IFRS reporting around the world: Early evidence on the economic consequences. Journal of Accounting Research, 46(5), 1085-1142.

Dietrich, J. R., Muller, K. A., \& Riedl, E. J. (2007). Asymmetric timeliness tests of accounting conservatism. Review of Accounting Studies, 12, 95-124.

Dye, R. (2001). An evaluation of 'essays on disclosure' and the disclosure literature in accounting. Journal of Accounting and Economics, 32, 181-232.

Easley, D., \& O'Hara, M. (2004). Information and the cost of capital. The Journal of Finance, 59(4), $1553-1583$.

Easton, P., \& Monahan, S. (2005). An evaluation of accounting-based measures of expected returns. The Accounting Review, 80(2), 501-538.

Easton, P., \& Sommers, G. (2007). Effect of analysts' optimism on estimates of the expected rate of return implied by earnings forecasts. Journal of Accounting Research, 45, 983-1015.

Fama, E., \& French, K. R. (1992). The cross-section of expected returns. The Journal of Finance, 47(2), $427-465$.

Fama, E., \& French, K. R. (1993). Common risk factors in the returns of stocks and bonds. Journal of Financial Economics, 33, 3-56.

Fama, E., \& French, K. R. (1997). Industry costs of equity. Journal of Financial Economics, 43, $153-193$.

Fama, E., \& MacBeth, J. (1973). Risk, return, and equilibrium: Empirical tests. Journal of Political Economy, 81, 607-636.

Francis, J., LaFond, R., Olsson, P., \& Schipper, K. (2004). Cost of equity and earnings attributes. The Accounting Review, 79(4), 967-1010.

Francis, J., LaFond, R., Olsson, P., \& Schipper, K. (2005). The market pricing of earnings quality. Journal of Accounting and Economics, 39, 295-327.

Francis, J. R., \& Martin, X. (2010). Acquisition profitability and timely loss recognition. Journal of Accounting and Economics, 49(1-2), 161-178.

Francis, J., Nanda, D., \& Olsson, P. (2008). Voluntary disclosure, earnings quality and cost of capital. Journal of Accounting Research, 46(1), 53-99.

García Lara, J., García Osma, B., \& Penalva, F. (2009a). Accounting conservatism and corporate governance. Review of Accounting Studies, 14(1), 161-201.

García Lara, J., García Osma, B., \& Penalva, F. (2009b). The economic determinants of conditional conservatism. Journal of Business Finance and Accounting, 36, 336-372. 
Gibbons, M. R., Ross, S. A., \& Shanken, J. (1989). A test of the efficiency of a given portfolio. Econometrica, 57(5), 1121-1152.

Givoly, D., \& Hayn, C. (2000). The changing time-series properties of earnings, cash flows and accruals: Has financial reporting become more conservative? Journal of Accounting and Economics, 29, 287320.

Givoly, D., Hayn, C., \& Natarajan, A. (2007). Measuring reporting conservatism. The Accounting Review, $82(1), 65-106$.

Gompers, P., Ishii, J., \& Metrick, A. (2003). Corporate governance and equity prices. Quarterly Journal of Economics, 118, 107-155.

Graham, J. R., Harvey, C. R., \& Rajgopal, S. (2005). The economic implications of corporate financial reporting. Journal of Accounting and Economics, 40, 3-73.

Guay, W., \& Verrecchia, R. E. (2007). Conservative disclosure. Working paper. University of Pennsylvania.

Hribar, P., \& Jenkins, T. (2004). The effect of accounting restatements on earnings revisions and the estimated cost of capital. Review of Accounting Studies, 9, 337-356.

Hughes, J., Liu, J., \& Liu, J. (2009). On the relation between expected returns and implied cost of capital. Review of Accounting Studies, 14, 246-259.

Khan, M., \& Watts, R. L. (2009). Estimation and empirical properties of a firm-year measure of accounting conservatism. Journal of Accounting and Economics, 48, 132-150.

Kravet, T., \& Shevlin, T. (2007). Accounting restatements and information risk. Working paper. University of Washington.

LaFond, R., \& Watts, R. (2008). The information role of conservatism. The Accounting Review, 83, 443478.

Lambert, R., Leuz, C., \& Verrecchia, R. (2007). Accounting information, disclosure, and the cost of capital. Journal of Accounting Research, 45(2), 385-420.

Lambert, R., Leuz, C., \& Verrecchia, R. (2008). Information asymmetry, information precision, and the cost of capital. Working paper University of Pennsylvania.

Levitt, A. (1998). The importance of high quality accounting standards. Accounting Horizons, 12(1), 7982.

Li, X. (2009). Accounting conservatism and cost of capital: International analysis. Working paper. London Business School.

McInnis, J. M. (2010). Earnings smoothness, average returns, and implied cost of equity capital. The Accounting Review, 85, 315-341.

Merton, R. (1987). A simple model of capital market equilibrium with incomplete information. The Journal of Finance, 42(3), 483-510.

Patatoukas, P., \& Thomas, J. (2009). Evidence of conditional conservatism: fact or artifact? Working paper. Yale University.

Penman, S., \& Zhang, X. (2002). Accounting conservatism, the quality of earnings, and stock returns. The Accounting Review, 77(2), 237-264.

Petersen, M. A. (2009). Estimating standard errors in finance panel data sets: Comparing approaches. Review of Financial Studies, 22, 435-480.

Petkova, R. (2006). Do the Fama-French factors proxy for innovations in predictive variables? The Journal of Finance, 61, 581-612.

Pope, P. F., \& Walker, M. (1999). International differences in the timeliness, conservatism and classification of earnings. Journal of Accounting Research, 37(Supplement), 53-99.

Qiang, X. (2007). The effects of contracting, litigation, regulation, and tax costs on conditional and unconditional conservatism: cross-sectional evidence at the firm level. The Accounting Review, 82, $759-797$.

Shanken, J. (1992). On the estimation of beta-pricing models. Review of Financial Studies, 5, 1-34.

Shanken, J., \& Weinstein, M. (2006). Economic forces and the stock market revisited. Journal of Empirical Finance, 13, 129-144.

Sloan, R. G. (1996). Do stock prices fully reflect information in accruals and cash flows about future earnings? The Accounting Review, 71, 289-315.

Suijs, J. (2008). On the value relevance of asymmetric financial reporting policies. Journal of Accounting Research, 46(5), 1297-1321.

Vuolteenaho, T. (2002). What drives firm-level stock returns. The Journal of Finance, 57, 233-264.

Watts, R. (2003). Conservatism in accounting Part I: Explanations and implications. Accounting Horizons, 17(3), 207-221. 